\title{
Suppression of B-Cell Differentiation by Leukocytes from
}

\section{Hypogammaglobulinemic Patients}

\author{
Frederick P. Siegal, Marta Siegal, and Robert A. Good \\ From the Clinical Immunology Service, Department of Medicine, Memorial \\ Hospital, and the Sloan-Kettering Institute, New York 10021
}

A B S T RA C T Leukocytes from patients with several forms of immunodeficiency characterized by apparently differing defects in B-lymphocyte maturation produced few or no plasmacytoid cells in vitro, and were capable of suppressing the generation of plasma cells in co-culture with cells of normal persons, in the presence of pokeweed mitogen. Such inhibition was commonly observed in cultures which included cells from patients with primary immunoglobulin deficiency, but was not seen to a significant degree in identical co-cultures of cells from normals. The suppression observed was not dependent upon mixed leukocyte culture reactivity. Both sheep erythrocyte-rosetting lymphocytes and adherent cells appeared to participate in these effects in some patients. In one patient with common variable immunodeficiency, but not in several others, removal of suppressing cells permitted the patient's remaining cells to differentiate into plasma cells in vitro. Because of the diverse syndromes in which suppression was observed, it is likely that, in at least some hypogammaglobulinemic patients, the suppression is secondary to the disease process rather than being the primary pathogenic mechanism.

\section{INTRODUCTION}

Most patients with hypogammaglobulinemia have deficient or absent plasma cells in bone marrow, lymphoid tissue (1), and gut (2). Such patients represent a variety of immunodeficiency states, in certain of which both cellmediated and humoral immune systems are involved (3). Since the advent of methods permitting the identification of small lymphocyte subpopulations (4), it has become possible to pinpoint a variety of defects in the development of the cells which comprise the humoral

\footnotetext{
A portion of this work was presented at the meetings of the American Federation for Clinical Research, May, 1975, Clin. Res. 23: 297A. (Abstr.)

Received for publication 5 September 1975 and in revised form 5 March 1976.
}

limb of the immune system (reviewed in 5). Patients with Bruton-type (infantile, X-linked) agammaglobulinemia seem to have a defect in the earliest stages of bone marrow-derived-(B) lymphocyte development, and generally lack cells clearly identifiable as $\mathrm{B}$ cells. Patients with thymoma and immunodeficiency also often seem to lack B cells. In one such patient, circulating cells were present which could differentiate in vitro into apparently normal B cells (6). Some of these patients may therefore have a block at an intermediate stage of B-lymphocyte differentiation. A third pattern is seen in patients with the heterogeneous syndromes of common variable immunodeficiency. The cells of most of these patients seem capable of differentiating normally to the stage of mature $B$ lymphocytes, but are unable in vivo to undergo significant terminal differentiation into secreting plasma cells $(5,7-9,12)$.

Reports of studies on the ability of the cells of various hypogammaglobulinemic patients to synthesize and secrete immunoglobulins ( $\mathrm{Ig}$ ) in vitro (10), taken together with electronmicroscopic (11) or immunofluorescent $(7,8,12)$ studies of terminal differentiation, indicate that the ability of a cell to produce and secrete large amounts of immunoglobulin is closely linked to morphologic differentiation into plasmacytoid cells. Such cells are characterized by the development of large amounts of rough endoplasmic reticulum and of cytoplasmic Ig.

Cells capable of suppressing various immunologic functions have been recently described in experimental animal systems (14), and are thought to participate in the physiologic control of the immune response.

Waldmann et al. have reported cell-mediated suppression of Ig synthesis in some patients with common variable immunodeficiency (CVI). ${ }^{1}$ They have proposed that,

\footnotetext{
${ }^{1}$ Abbreviations used in this paper: CVI, common variable immunodeficiency; FCS, fetal calf serum; F/P value, ratio of plasma cells found to those predicted; HBSS, Hanks' balanced salt solution; NLC, nonlymphoid cells; PBS, phosphate-buffered saline; PWM, pokeweed mitogen.
} 


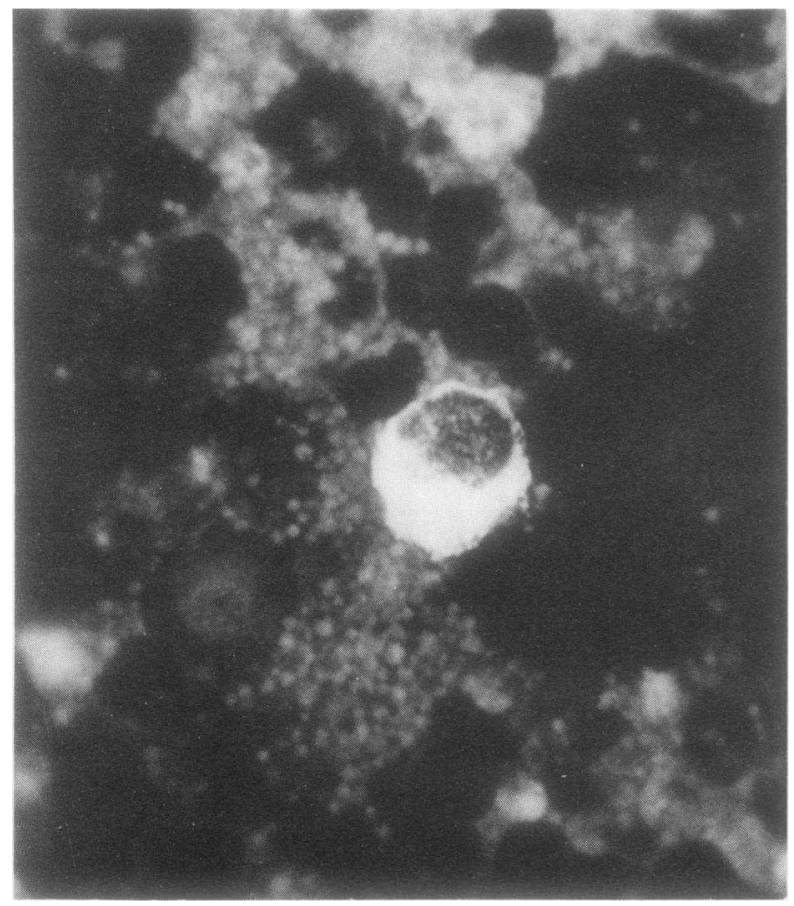

FIGURE 1 Plasmacytoid cell from pokeweed mitogen-stimulated 7-day culture of cells from a normal person. One cell, with eccentric nucleus and bright intracytoplasmic staining for immunoglobulin, stands out among the other negatively staining cells. $(\times 580)$.

in at least some patients, excess suppressor activity is a major pathogenetic mechanism of the immunodeficiency (12).

We here report the finding of cell-dependent suppressor phenomena in patients having a variety of syndromes of impaired B-lymphocyte differentiation representing several steps along the pathway to the plasma cell.

\section{METHODS}

Patients investigated were selected from a clinic population of immunodeficient adults and children. Patients were chosen for study largely on the basis of availability for repeated analysis and a relatively well-defined disease, although certain patients were studied because they fell into specific categories (e.g., all available patients with Bruton-type agammaglobulinemia were examined). Patients were classified according to the recommendations of the Expert Committee of the World Health Organization (15). Base-line information on the patients is included in Table I. Normal blood donors and adult laboratory personnel served as controls.

Peripheral blood was heparinized $(20 \mathrm{U} / \mathrm{ml})$ under sterile conditions, diluted $1: 2$ with physiologic saline, and separated on Ficoll-Hypaque according to Böyum (16). Mononuclear cell fractions from normal subjects, as isolated in our laboratory, contain $10-50 \%$ (mean $=28 \%$ ) phagocytic (latex-ingesting) cells, and nonphagocytic cells having the following characteristics $(\%)$ : surface Ig (polyvalent), 21.2 \pm 6.8 ; IgM, $7.4 \pm 3.5 ; \operatorname{IgD}, 3.9 \pm 2.3 ; \mathrm{Fc}$ receptor (aggregates), 21.8 \pm 7.7 ; and sheep rosette-forming cells: 79.7 \pm 7.9 . The resulting mononuclear cell layer was washed three times in 'Hanks' balanced salt solution (HBSS) and finally adjusted to $1 \times$ $10^{\circ}$ lymphocytes/ml in RPMI 1640 (Grand Island Biological Co., Grand Island, N. Y.) supplemented with $20 \%$ fetal calf serum (FCS), nonessential amino acids, and glutamine, penicillin and streptomycin. Cells were cultured in this medium, usually without the further addition of nutrients, for a week, in the presence of pokeweed mitogen (PWM) (Grand Island Biological $\mathrm{Co}_{\mathrm{o}}$ ). In preliminary experiments with normal individuals, the dose-response curve (10-fold increments) for the end point (plasma cell generation) was determined to be relatively flat; subsequently, the proportion of PWM added was $10 \mu \mathrm{l} / \mathrm{ml}$ culture volume. A 1-week incubation period was utilized to permit the development of adequate numbers of plasma cells in the normal subjects' cell cultures. Although rare plasma cells were detectable at 3 days of culture, significant numbers of such cells did not appear in preliminary trials until 4 days had elapsed.

The initial cell concentration in the cultures was adjusted on the basis of the number of lymphocytes. Cells from different subjects were cultured separately or co-cultured in mixtures at varying ratios. Normal cells were co-cultured with other normal cells under identical conditions.

In the early experiments, cultures were carried out in $30-\mathrm{ml}$ plastic disposable flat-bottomed culture flasks (Falcon Plastics, Division of BioQuest, Oxnard, Calif.), at volumes of 4-6 $\mathrm{ml}$, initially containing $1 \times 10^{8}$ lymphocytes $/ \mathrm{ml}$. When cell numbers were severely limited, and later, routinely, smaller volumes (1-3 ml) were cultured, usually at $1 \times 10^{\circ}$ cells/ml in plastic round-bottomed 15-cc test tubes (Falcon Plastics). Because of geometrical considerations involved in the different culture systems, appropriate controls utilizing identical cell concentrations, volumes, and containers were always run when deviations from the flat-bottomed flasks were required. Because of limitations of available cell numbers, duplicate cultures were not run in all experiments, but were done whenever the initial cell yield permitted. Data from 19 sample paired identical cultures done during the series of experiments were statistically analyzed.

Cultures were terminated on day 7 ; the cells were counted with trypan blue to assess the absolute yield of viable cells from each culture, as trypan blue excluding cells per milliliter. No attempt was made at this time to differentiate between lymphoid and nonlymphoid cells, but most of the cells recovered on slides and stained with tetrachrome appeared to be lymphoid.

The cells were then pelleted, and the cell pellets was washed once in bovine albumin $(2 \mathrm{~g} / 100 \mathrm{ml})$ in phosphatebuffered saline (PBS), and adjusted to an appropriate volume. Cytocentrifuge smears were prepared and stored frozen at $-20^{\circ} \mathrm{C}$. For immunofluorescent staining, slides were thawed, dessicated, fixed in 5\% (vol/vol) glacial acetic acid in methanol at $-20^{\circ} \mathrm{C}$, washed three times in PBS, and stained with the antiglobulin reagent at room temperature for $30 \mathrm{~min}$ in a moist chamber. The slides were washed three times again in PBS, once in distilled water, and air dried.

The antiserum used in the present study was a mixture of two rabbit antisera, having combined specificities in Ouchterlony analysis for mu, gamma, kappa, and lambda determinants, prepared as described previously (9).

Microsoopy was carried out using a Leitz Orthoplan microsoope (E. Leitz, Inc., Rockleigh, N. J.) equipped for fluorescence with a Ploem incident illuminator (9).

Coded fluorescence-labeled slides were read by a single observer (Dr. F. P. Siegal). The code was broken only 
after the entire set of slides in a particular experiment had been read, to reduce the possibility of observer bias. A minimum of 1,000 cells was counted from each culture, recorded as paired counts of 500 or more cells.

For purposes of this study, cells were regarded as plasma cells if they had brightly stained cytoplasmic Ig. There was a wide morphologic spectrum of such cells; they were not morphologically distinct, other than in their fluorescence, from the negative cells in the same cultures. Some were large, clearly plasmacytoid cells with abundant cytoplasm and eccentric nuclei; others were more lymphoid. Generally, small lymphocytes were negative for Ig.

When viewed with rhodamine-specific illumination, negative cells gave a faint red glow; the cytoplasm of positive cells stained bright red, with a diffuse or slightly granular cytoplasmic fluorescence, and stood out in sharp contrast to the cell nucleus and to the background cells (Fig. 1). Occasional cells containing Russell bodies were seen. Under blue or ultraviolet illumination, negative cells were green and positive cells orange; such cells were always confirmed with rhodamine-specific illumination; because of the extremely faint background in some slides, negative cells were often best visualized using blue exciting wavelengths as for fluorescein.

In certain experiments, adherent cells were removed on nylon wool columns before culture, by incubation at $37^{\circ} \mathrm{C}$ for $30-90 \mathrm{~min}$ in $20 \% \mathrm{FCS}$. Nonadherent cells were eluted stepwise with aliquots of HBSS at room temperature. The column was finally washed with calcium- and magnesiumfree HBSS with vigorous agitation to elute some of the adherent cells. The proportion of nonlymphoid cells in the eluted cell fractions was first enumerated in a counting chamber and then confirmed on cytocentrifuge smears by morphology and by nonspecific peroxidase staining, combined with tetrachrome.

Cells forming relatively stable rosettes with sheep erythrocytes were separated from nonrosetting cells by a modification of the method of Bentwich et al. (17). 1-ml aliquots of $5 \times 10^{6}$ mononuclear cells in HBSS were mixed with an equal volume of $0.5 \%$ washed sheep erythrocytes in $10 \%$ heat-inactivated human AB serum previously absorbed with sheep red blood cells, in $15-\mathrm{ml}$ round-bottomed plastic test tubes, incubated for $10 \mathrm{~min}$ at $37^{\circ} \mathrm{C}$, pelleted for $10 \mathrm{~min}$ at $20 \mathrm{~g}$, and kept at $4^{\circ} \mathrm{C}$ overnight. Unseparated cells from the same patient and from the normal donor were also held overnight at $4^{\circ} \mathrm{C}$ for appropriate controls. The rosetting mixtures were gently resuspended, layered over FicollHypaque, and centrifuged for $20 \mathrm{~min}$ at $400 \mathrm{~g}$. The resulting pellets and interface cells were then pooled and washed several times before culture. Sheep erythrocytes were lysed by exposure to $0.83 \% \mathrm{NH}_{4} \mathrm{Cl}$. A sampling of the efficiency of rosette formation after resuspension from such large volumes was compared with the $0.2-\mathrm{ml}$ rosetting mixtures ordinarily used. This procedure left approximately $20-30 \%$ of the cells which would be expected to form rosettes in the nonrosetting fraction (interface). Many cells usually regarded as thymus-derived ( $T$ ) lymphocytes were present in the interface fraction, which also contained a substantial proportion of monocytes.

To screen for serum-mediated inhibition of plasma cell generation, frozen sera from patients studied were inactivated at $56^{\circ} \mathrm{C}$ for $30 \mathrm{~min}$. To normal lymphocytes cultured under the conditions described in $2 \mathrm{ml}$ of culture medium with $20 \%$ FCS, was added $0.2 \mathrm{ml}$ of the inactivated serum. Pooled human AB serum, serum from random normal adult laboratory workers, and additional FCS were used as negative controls. The proportion of plasma cells and total cell yields in these cultures were compared to the same findings under standard $(20 \%$ FCS) culture conditions.

Lymphocyte stimulation with mitogens (phytohemagglutinin, concanavalin A, PWM) for incorporation of tritiated thymidine were carried out at other times on the same patients, by Doctors Bo Dupont and John Hansen, as described elsewhere (18). These data will be reported in a subsequent publication. Immunoglobulin quantitations were done by radial immunodiffusion on commercial plates (Behringwerke, Behring Diagnostics, American Hoechst Corp., Somerville, N. J.). Analysis of lymphocyte subpopulations was carried out essentially as described (19), using as surface markers antisera monospecific for mu, delta, gamma, alpha, kappa, and lambda determinants; aggregated IgG (Fc receptor); and spontaneous sheep erythrocyte rosettes.

Statistical analysis of the methodologic error was done by taking into account the errors of sample replicate cultures, replicate counts, and of dilution and cell counting in mixing experiments. The confidence intervals for $F / P$ values were generated using these error estimates in an approximate Poisson procedure on the constituent counts, then translated to the terms of the $F / P$ value. Student's $t$ test was utilized in determining statistical significance.

As an index of suppression or enhancement of plasma cell generation in the cultures, the ratio of plasma cells found to those predicted on the basis of dilution ( $F / P$ value) was calculated :

$$
\begin{gathered}
F / P \text { value }=\frac{\text { Proportion of plasma cells found }}{\text { Proportion of plasma cells predicted' }}, \\
\frac{\text { Proportion of plasma }}{\text { cells predicted }(P)}=\frac{A\left(P_{A}\right)+B\left(P C_{B}\right)}{A+B},
\end{gathered}
$$

where $A$ and $B$ are the relative proportions of lymphocytes from subjects $A$ and $B$, in whole numbers, at the start of the mixed cultures, $\mathrm{PC}_{\mathbf{A}}$ and $\mathrm{PC}_{\mathrm{B}}$ are the plasma cell proportions recovered from cultures of cells from subjects $A$ and B, when cultured separately.

\section{RESULTS}

\section{Culture of normal or immunodeficient cells with PWM}

Culture of mononuclear cells from 32 individual normal adult donors in the presence of the standard concentration of PWM always led to the production of plasma cells, ranging from 6.6 to 233 per 1,000 cells recovered, with a mean of 54.2 (Fig. 2). In contrast to the results in normals, cells from hypogammaglobulinemic patients of all types were deficient in the production of plasma cells under identical conditions; only 1 of 17 patients studied (Ro, with CVI) produced any cells in vitro showing the characteristic cytoplasmic fluorescence. That patient's initial culture developed 2 plasma cells/ 1,000 cells recovered; later experiments with her cells yielded 65.4 and 34.8/1,000 positive cells. Despite these abnormalities in generation of plasma cells by the patients, virtually all of them had a normal mitotic response to PWM (see Table I). Yields of viable cells after 7 days of culture were similar for patients $(110.1 \%$, 


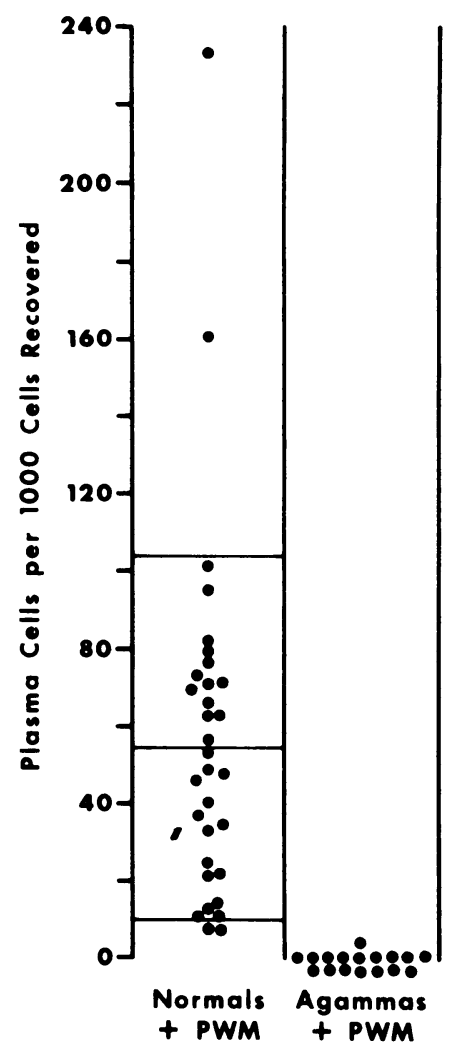

Figure 2 Frequency of plasmacytoid cells recovered from cultured lymphocytes from normal and hypogammaglobulinemic subjects after 7 days of incubation with pokeweed mitogen. Ordinate, plasma cells per 1,000 cells recovered. Cells from: (left) normals; (right) hypogammaglobulinemic patients.

range $40-172 \%)$ and normal controls $(107.2 \%$, range $22-294 \%$ ). The morphologic heterogeneity of the cells from both normal and patient cell cultures was similar, except for the Ig staining.

\section{Reproducibility of the method}

The relatively simple approach used in this study was evaluated for its reproducibility and found to be quite reliable. Analysis of the 19 duplicate culture pairs showed that the deviation from the mean of paired cultures was no more than that expected from a Poisson distribution, as was the counting error in paired counts of 500 cells each from a given culture. Most of the normal control samples were from blood bank donors, who could not be studied repeatedly. The proportion of plasmacytoid cells found at the termination of these cultures varied considerably (see above). The cells of one normal individual were, however, utilized as the control in seven experiments over the period of the study. The variability of PWM response in that (mean $51.5, \pm 38.4,1 \mathrm{SD}$ ), (range 7-116 plasmacytoid cells per 1,000 cells recovered) was comparable to that of the group of normals as a whole (see above). Some of this variation is related to the use of two different culture conditions (i.e., flasks or round-bottomed tubes) in different experiments, and some to individual variation. For example, the cells of four normal adults cultured on the same day produced from 24 to 80 plasmacytoid cells per 1,000 cells recovered.

\section{Mixed culture, normals}

Co-culture of cells from pairs of normal donors led to plasma cell generation at both $1: 1$ and $1: 2$ cell ratios (donor $1:$ donor 2 ). The overall proportion of plasma cells found in the mixed cultures of normals was slightly greater than would have been expected from dilutional factors alone (Fig. 3). In 11 co-cultures, at $1: 1$ cell mixtures, the ratio of plasma cells found to those predicted by mixing alone $(\mathrm{F} / \mathrm{P}$ value $)$ was $1.16 \pm 0.24$ ( 1 $\mathrm{SD})$. The lowest $\mathrm{F} / \mathrm{P}$ value found for an individual coculture of normals was $0.88 \pm 0.18$. At donor cell ratios of $1: 2$, the mean $\mathrm{F} / \mathrm{P}$ value was also above unity

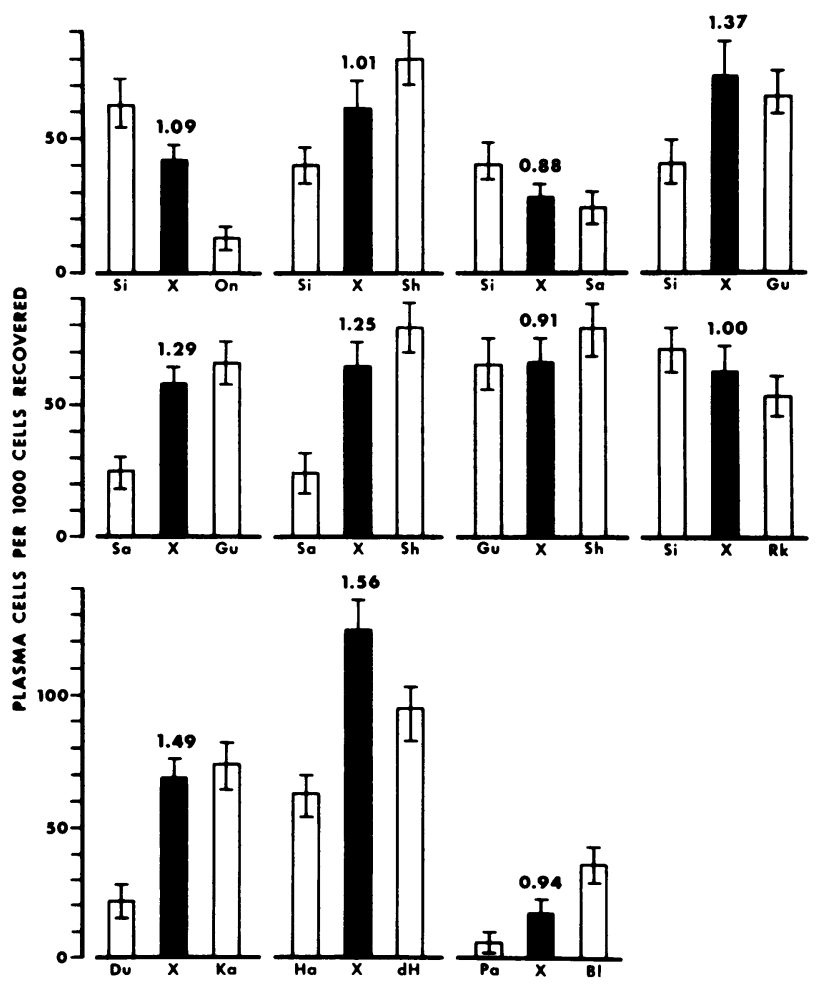

Figure 3 7-day cultures of cells from normal persons. Open bars : cells of one normal subject cultured alone. Black bars, cells of both normal subjects (open bars on either side) co-cultured. Ordinate, plasma cells per 1,000 cells recovered. Number over black bar, F/P value for the mixed culture, the ratio of plasma cells found (black bar) to those predicted on the basis of results of the individual cultures (open bars). 
TABLE I

Patients Studied for Suppressor Activity

\begin{tabular}{|c|c|c|c|c|c|c|c|c|c|c|c|c|}
\hline \multirow[b]{3}{*}{ Patient } & \multirow[b]{3}{*}{ Sex } & \multirow[b]{3}{*}{ Age } & \multirow{2}{*}{\multicolumn{3}{|c|}{ Mitogen responses }} & \multicolumn{4}{|c|}{ Lymphocyte markers } & \multirow{2}{*}{\multicolumn{3}{|c|}{ Immunoglobulins }} \\
\hline & & & & & & & & & & & & \\
\hline & & & PHA & Con $\mathbf{A}$ & PWM & receptor & IgM & IgD & SRFC & IgG & IgM & $\operatorname{IgA}$ \\
\hline & & \multicolumn{4}{|l|}{$y r$} & \multicolumn{4}{|c|}{$\%$} & \multicolumn{3}{|c|}{$m g / 100 m l$} \\
\hline \multicolumn{13}{|c|}{ Variable immunodeficiency } \\
\hline $\mathrm{Sc}$ & $\mathrm{F}$ & 51 & - & - & - & 14.5 & 5.6 & 6.0 & 91.5 & 360 & 336 & 2.5 \\
\hline $\mathrm{La}$ & $\mathbf{M}$ & 38 & - & $\mathrm{ND}^{*}$ & ND & 0.5 & 0.5 & 1.0 & 92.5 & 110 & $<5$ & $<5$ \\
\hline Ros & $\mathrm{F}$ & 41 & + & + & + & 7.0 & 3.3 & 6.0 & 93.0 & 36 & 82 & 0 \\
\hline $\mathrm{Ch}$ & $\mathrm{F}$ & 23 & + & + & + & 6.2 & 1.5 & 1.5 & 89.5 & 220 & 1 & 0 \\
\hline Ro & $\mathrm{F}$ & 27 & + & + & + & 26.0 & 16.0 & ND & 86.0 & 180 & 80 & 0 \\
\hline Co & $\mathbf{M}$ & 45 & + & ND & + & 14.0 & 5.2 & 4.8 & 86.2 & 58 & $<5$ & 0 \\
\hline Ed & $\mathbf{M}$ & 18 & ND & ND & ND & 11.0 & 4.0 & 5.0 & 91.0 & 40 & 2 & $<3$ \\
\hline $\operatorname{Pr}$ & $\mathbf{M}$ & 6 & ND & ND & ND & ND & ND & ND & ND & 160 & 38 & 0 \\
\hline \multicolumn{13}{|c|}{ Bruton's agammaglobulinemia } \\
\hline $\mathrm{Ma}$ & $\mathbf{M}$ & 21 & + & + & + & 24.5 & 0 & 0 & 79.0 & 104 & $<5$ & $<5$ \\
\hline $\mathrm{Ar}$ & $\mathbf{M}$ & 6 & + & + & + & 15.6 & 0 & 0 & 86.2 & 41 & 0 & 0 \\
\hline $\mathrm{Ri}$ & $\mathbf{M}$ & 20 & + & + & + & 5.0 & 0 & 0 & 80.0 & 44 & 0 & 0 \\
\hline Har & $\mathbf{M}$ & 24 & + & + & + & 7.0 & 0 & 0 & 83.0 & $660 \ddagger$ & 5 & $<1$ \\
\hline Haa & $\mathbf{M}$ & 8 & - & - & + & 7.0 & 0 & 0 & 95.5 & $340 \ddagger$ & $<5$ & $<5$ \\
\hline $\mathrm{Ta}$ & $\mathbf{M}$ & 10 & + & + & + & 5.3 & 0 & 0 & 88.6 & $190 \ddagger$ & 0 & 0 \\
\hline \multicolumn{13}{|c|}{ Thymoma with immuna eficiency } \\
\hline $\mathbf{K a}$ & $\mathbf{M}$ & 52 & + & - & + & 19.0 & 0 & 0 & 79.5 & 100 & $<2$ & 0 \\
\hline
\end{tabular}

Mitogen responses: + , normal result: $\mathrm{cpm}$ and stimulation index similar to that of a simultaneous control; - , weak or no response compared to simultaneous control.

Abbreviations: Con A, concanavalin A; PHA, phytohemagglutinin; SRFC, sheep rosette-forming cells.

* Not determined.

$\ddagger$ Patient receiving intensive IgG therapy at the time of study; lower base-line results were found elsewhere at time of diagnosis.

$(1.07 \pm 0.61,1 \mathrm{SD})$, but some lower values were encountered, the range being from 0.40 to 1.59 (Fig. 4).

Mixed culture, hypogammaglobulinemic states

Common variable immunodeficiency (Fig. 5). The cells of eight of these patients co-cultured with normal cells showed low F/P ratios in 9/11 trials. All patients demonstrated some degree of suppressor activity. In two trials, the normal control alone generated fewer than 15-20 plasma cells $/ 1,000$ cells recovered. Under these conditions, the statistical significance of an apparent enhancement of plasma cell generation could not be assessed; the possible biological significance of these results remains in doubt. In all cases in which statistically adequate numbers of plasma cells were generated by the normal, suppression occurred. An $F / P$ value 2 $\mathrm{SD}$ below the mean $\mathrm{F} / \mathrm{P}$ value for co-cultures of normal cells (less than 0.68 for starting cell ratios of $1: 1$ ) was regarded as showing suppression.

Bruton-type agammaglobulinemia. Five of six patients with this diagnosis showed clear-cut suppressor activity at $1: 1$ starting ratios of patient: normal cells (Table II). Repeated analysis with one such patient
(Ma) mixed with different normal cells at times showed suppressor activity at 1:1 ratios, but at times did not. On one occasion when there was no demonstrable effect at $1: 1$, suppression was observable in the mixtures which contained patient: normal cells in a $2: 1$ ratio. This is discussed further below.

The cells of one patient (Ar), whose younger brother was also affected but was not studied, appeared to enhance the production of plasma cells in vitro $(F / P$ value 2.1). This result was reproducible over several cell ratios with the normal control (Table II), all below $1: 1$ (patient:normal). A patient-normal cell ratio of $2: 1$ was not tested, because of the paucity of patient cells. This was the only such result in the series in which the normal cells alone produced sufficient numbers of plasma cells to permit an apparent enhancement to be considered significant (see above).

Thymoma with immunodeficiency. The one patient available for study was co-cultured with two different normal subjects in three trials. Low $F / P$ values were observed in co-culture with one unrelated normal at $1: 1$ starting ratios of patient: normal cells, on two separate occasions. Increased suppression was observed at 2:1 


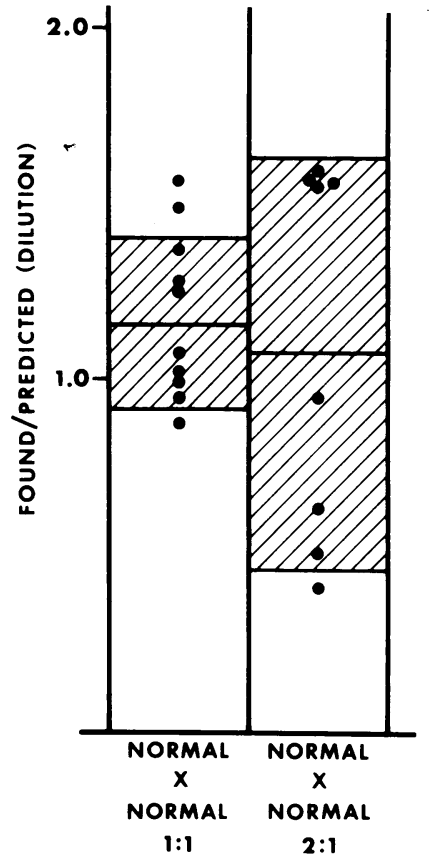

FIGURE 4 Co-cultures of pairs of normal individuals. Ordinate, $\mathrm{F} / \mathrm{P}$ value. An $\mathrm{F} / \mathrm{P}$ value of 1.0 would indicate neither suppression nor enhancement of plasma cell generation. Left, cells of normals co-cultured at 1:1 ratios. Mean $\mathrm{F} / \mathrm{P}$ value $=1.16 \pm 0.24$ ( $1 \mathrm{SD})$. Right, cells of normals co-cultured at $2: 1$ ratios. Mean $F / P$ value $=1.07 \pm 0.61$ (1 SD).

ratios. The second normal, the patient's HLA-identical, mixed-leukocyte culture-matched twin brother, was also suppressed, but only at starting cell ratios of $2: 1$ (Fig. $6)$.

Effect of varying the ratio of patient: normal cells

Mononuclear cells from hypo- or agammaglobulinemic patients were co-cultured with normal mononuclear cells at starting ratios varying from $1: 9$ to $2: 1$ (patient: normal). Although most conveniently depicted in patients with Bruton-type agammaglobulinemia (Fig. 7), the results were similar in all categories in immunodeficiency studied. The greater the ratio of patient: normal cells, the greater was the degree of suppression observed. At 1:1 ratios, the patient-normal mixed cultures were significantly different from the normal-normal cultures $(P<0.001)$. The cells of certain normals cocultured at ratios other than $1: 1$ gave $\mathrm{F} / \mathrm{P}$ values considerably below 1 , while others were above that ideal value. Co-cultures of hypogammaglobulinemic cells of all types at 2:1 ratios with cells from normals usually gave $\mathrm{F} / \mathrm{P}$ values lower than those seen for any of the normal co-cultures. These differences between normal cells co-cultured at 2:1 ratios and normals co-cultured with hypogammaglobulinemic cells at $2: 1$ were also highly significant $(P<0.001)$ (Fig. 8). Moreover, the five patients whose $\mathrm{F} / \mathrm{P}$ values at $1: 1$ ratios were normal or borderline low all fell below any of the normal co-cultures when their cells were co-cultured at $2: 1$. Certain hypogammaglobulinemic cells were apparently suppressive at ratios of patient: normal well below $1: 1$; thus, the cells of two patients with Bruton-type agammaglobulinemia (Fig. 7) and of one patient with CVI (data not shown) exhibited suppressor activity in cultures in which the starting mixture contained fewer than $20 \%$ patient cells; in these cases, inhibition of plasma cells in the final cultures was increasingly severe with increasing proportions of patient cells.

Relationship of final cell yield to suppressor activity in the mixed cultures

Mixed cultures at 1:1 ratios of patient to normal cells generally gave somewhat higher yields than did those individuals cultured separately.
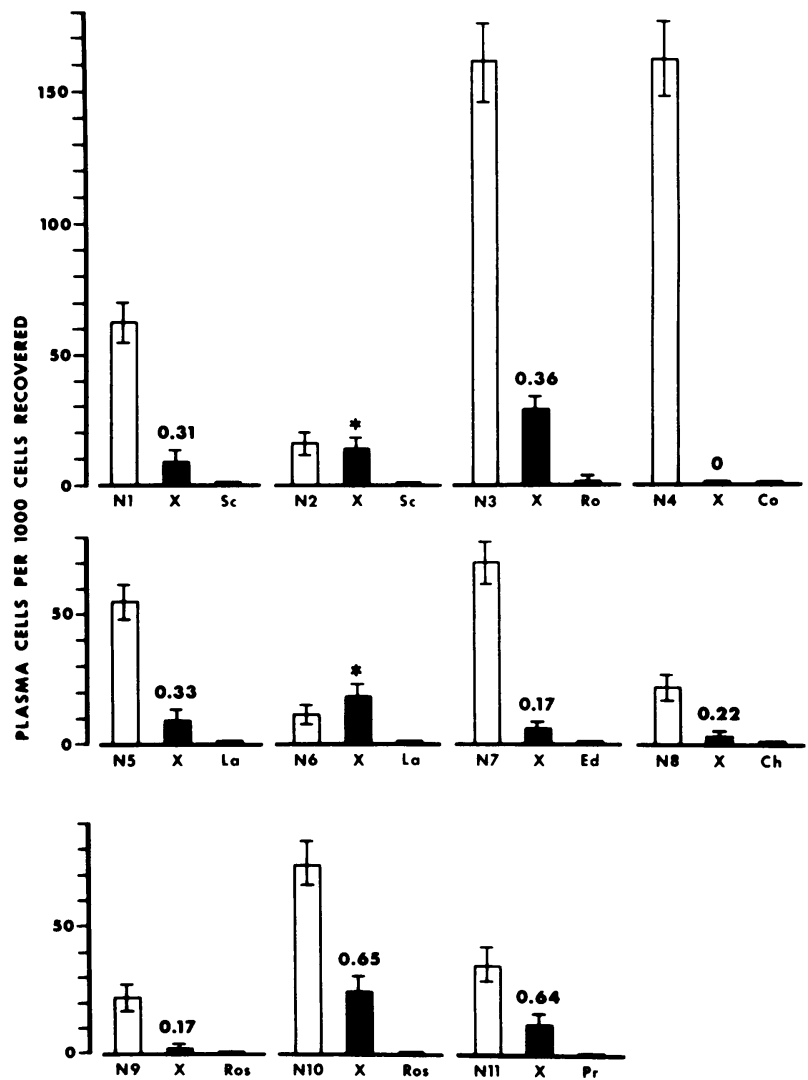

Figure 5 Co-cultures of cells of normal persons and of patients with CVI. The left-hand open bar of each triplet represents cells from a different normal control cultured alone; the right-hand bar (almost always zero), the hypogammaglobulinemic cells cultured alone; the central black bar, the co-culture of cells on either side. The number over the central bar in each triplet is the F/P value. See Fig. 3. Ordinate: plasma cells per 1,000 cells recovered. $* \mathrm{~F} / \mathrm{P}$ value was not calculated because of insufficient positive cells in the control culture. See text. 
When strongly suppressing 1:1 co-cultures of normal and patient cells $(\mathrm{F} / \mathrm{P}$ value $<0.2)$ were compared to nonsuppressing cultures $(\mathrm{F} / \mathrm{P}$ values $>0.91)$, the yields were $132.2 \%(24-167 \%)$ and $123.0 \%(30-228 \%)$ respectively.

\section{Effect of removing adherent cells}

In several experiments, adherent cells were removed from the patient's cell populations by passing the FicollHypaque-isolated cells over nylon fiber columns. The effluent fractions from these columns were then assayed for nonlymphoid cells by both morphology and the presence of peroxidase. The two criteria gave similar values. The results of the four positive experiments are shown in Table III. Patient Co, with common variable immunodeficiency, had not produced plasma cells in vitro on several trials. His unseparated mononuclear cell layer, containing $22 \%$ nonlymphoid cells, generated no plasma cells when cultured alone. When his cells were co-cultured with a normal person's cells, the mixture gave an $\mathrm{F} / \mathrm{P}$ value of $0.35 \pm 0.19$. After nylon column passage of the patient's cells, fractions containing 1.2 and $3.4 \%$ nonlymphoid cells (NLC) were recovered. The fraction containing only $1.2 \% \mathrm{NLC}$, when cultured alone, generated some plasma cells $(11.4 / 1,000$ cells recovered). In the mixture with unseparated normal cells, the $\mathrm{F} / \mathrm{P}$ value was $2.85 \pm 0.17$. This mixture therefore showed apparent enhancement rather than suppression, as did the mixture containing $3.4 \%$ patient NLC (which were

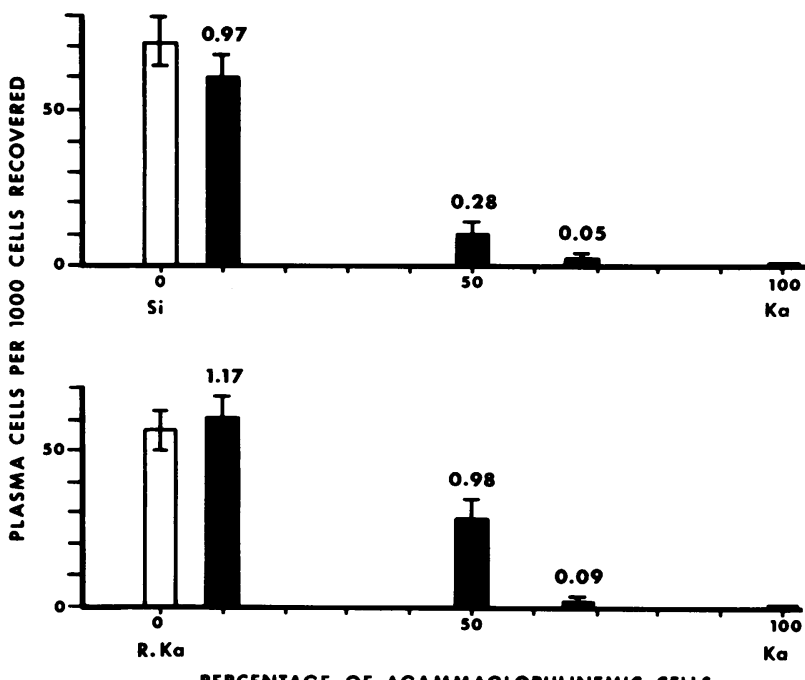

Figure 6 Co-culture of cells from normal subjects and a patient with thymoma with immunodeficiency. Abscissa, percentage of normal cells in the cultures, day 0. Ordinate, plasma cells per 1,000 cells recovered. Open bars, cells of normals cultured alone; black bars, co-cultures of normal and hypogammaglobulinemic cells. Upper panel, co-culture with cells from normal donor. Lower panel, co-culture with cells from normal identical twin.

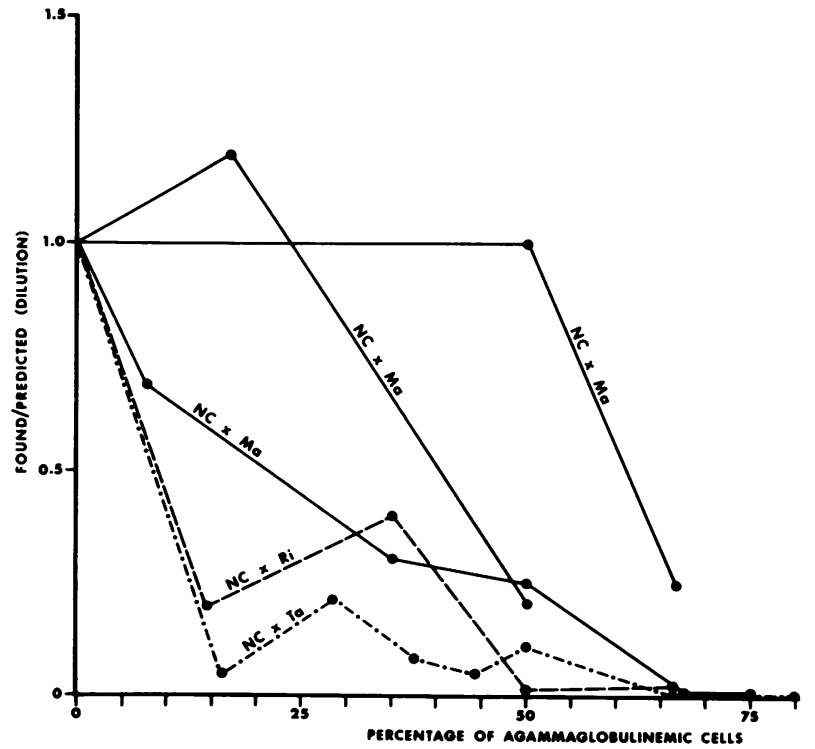

FIGURE 7 Effect of varying proportion of hypogammaglobulinemic cells in co-culture with cells from different normals, Bruton-type agammaglobulinemia. Abscissa, percentage of agammaglobulinemic cells at beginning of culture. Ordinate, $\mathrm{F} / \mathrm{P}$ value.

not cultured alone because of insufficient cells). Addition of patient monocytes mechanically eluted from the column (47\% NLC) to normal cells also did not suppress; but these adherent-eluted cells did not enhance the culture's ability to generate plasmacytoid cells.

Patient $\mathrm{Ma}$, with Bruton-type agammaglobulinemia, was studied in this way on three occasions in combination with different normal control subjects. In set one (Table III), the Ficoll-Hypaque mononuclear cells which contained $40 \%$ NLC did not suppress at $1: 1 \mathrm{ra}-$ tios, but at $2: 1$ there was inhibition $(\mathrm{F} / \mathrm{P}$ value, 0.33$)$. Nylon column passage yielded three fractions depleted of adherent cells to varying degrees, which were devoid of suppressing effects and of which two appeared to give significant enhancement to the net production of plasma cells. In set 2, Table III, there was suppression of the normal cells at $1: 1$ ratios of patient cells which contained $47 \%$ NLC; progressive reduction in the proportion of patient's NLC reduced the degree of suppression observed. Enhancement was not observed (F/P values greater than 1.64) and there was still some degree of suppression at $2: 1$ ratios in the presence of only $3 \%$ patient NLC. In set 3 , at $6 \%$ NLC, Ma cells alone did not generate any plasma cells despite the apparent effective removal of suppressor activity. Without removal of adherent cells, the Ma cells from set $3 \mathrm{com}$ pletely suppressed plasma cell generation by the normal's cells.

Similar studies on five other patients (thymoma with 
TABLE II

Bruton-Type Agammaglobulinemia

\begin{tabular}{|c|c|c|c|c|}
\hline \multirow{2}{*}{$\begin{array}{l}\text { Patient } \\
\text { (date) }\end{array}$} & \multirow{2}{*}{$\begin{array}{l}\text { Cells cultured } \\
\text { (ratio) }\end{array}$} & \multicolumn{2}{|c|}{ Plasma cells $/ 1,000$ cells } & \multirow[b]{2}{*}{$\mathrm{F} / \mathrm{P}$ value } \\
\hline & & Found & Predicted & \\
\hline $\begin{array}{l}\text { Ma } \\
(10 / 24 / 74)\end{array}$ & $\begin{array}{l}\mathrm{NC}^{*} \\
\mathrm{NC}+\mathrm{Ma}(1: 1) \\
\mathrm{Ma} \text { alone }\end{array}$ & $\begin{array}{r}13.5 \\
0.0 \\
0.0\end{array}$ & $\begin{array}{l}- \\
6.8 \\
-\end{array}$ & $\bar{t}$ \\
\hline $\begin{array}{l}\mathrm{Ma} \\
(12 / 6 / 74)\end{array}$ & $\begin{array}{l}\mathrm{NC} \text { alone } \\
\mathrm{NC}+\mathrm{Ma}(5: 1) \\
\mathrm{NC}+\mathrm{Ma}(1: 1) \\
\mathrm{Ma} \text { alone }\end{array}$ & $\begin{array}{r}76.6 \\
76.6 \\
8.2 \\
0.0\end{array}$ & $\begin{array}{l}- \\
63.8 \\
38.3 \\
-\end{array}$ & $\begin{array}{l}- \\
1.20 \\
0.21 \\
-\end{array}$ \\
\hline $\begin{array}{l}\mathrm{Ma} \\
(12 / 6 / 74)\end{array}$ & $\begin{array}{l}\mathrm{NC} \text { alone } \\
\mathrm{NC}+\mathrm{Ma}(1: 1) \\
\mathrm{Ma} \text { alone }\end{array}$ & $\begin{array}{r}110.1 \\
55.8 \\
0.0\end{array}$ & $\begin{array}{l}- \\
55.1 \\
-\end{array}$ & $\overline{1.01}$ \\
\hline $\begin{array}{l}\mathrm{Ma} \\
(1 / 8 / 75)\end{array}$ & $\begin{array}{l}\mathrm{NC} \text { alone } \\
\mathrm{NC}+\mathrm{Ma}(1: 1) \\
\mathrm{NC}+\mathrm{Ma}(1: 2) \\
\mathrm{Ma} \text { alone }\end{array}$ & $\begin{array}{r}94.8 \\
11.8 \\
0.0 \\
0.0\end{array}$ & $\begin{array}{l}- \\
47.4 \\
31.6 \\
-\end{array}$ & $\begin{array}{l}- \\
0.25 \\
0 \\
-\end{array}$ \\
\hline $\begin{array}{l}\mathrm{Ma} \\
(2 / 5 / 75)\end{array}$ & $\begin{array}{l}\mathrm{NC} \text { alone } \\
\mathrm{NC}+\mathrm{Ma}(1: 1) \\
\mathrm{NC}+\mathrm{Ma}(1: 2) \\
\mathrm{Ma} \text { alone }\end{array}$ & $\begin{array}{r}246.2 \\
121.6 \\
21.5 \\
0.0\end{array}$ & $\begin{array}{r}- \\
123.1 \\
82.1 \\
-\end{array}$ & $\begin{array}{l}- \\
0.99 \\
0.26 \\
-\end{array}$ \\
\hline $\begin{array}{l}\text { Tar } \\
(11 / 5 / 74)\end{array}$ & $\begin{array}{l}\text { NC alone } \\
\text { NC + Tar }(1: 1) \\
\text { Tar alone }\end{array}$ & $\begin{array}{r}81.9 \\
1.0 \\
0.0\end{array}$ & $\begin{array}{l}- \\
40.9 \\
-\end{array}$ & $\begin{array}{c}- \\
0.02 \\
-\end{array}$ \\
\hline $\begin{array}{l}\text { Tar } \\
(1 / 24 / 75)\end{array}$ & $\begin{array}{l}\text { NC alone } \\
\text { NC + Tar }(1: 1) \\
\text { Tar alone }\end{array}$ & $\begin{array}{r}32.7 \\
1.9 \\
0.0\end{array}$ & $\begin{array}{c}- \\
16.4 \\
-\end{array}$ & $\frac{-}{0.12}$ \\
\hline $\begin{array}{l}\mathrm{Ar} \\
(12 / 6 / 74)\end{array}$ & $\begin{array}{l}\mathrm{NC} \text { alone } \\
\mathrm{NC}+\operatorname{Ar}(7: 1) \\
\mathrm{NC}+\operatorname{Ar}(7: 2) \\
\mathrm{NC}+\operatorname{Ar}(7: 4) \\
\mathrm{NC}+\operatorname{Ar}(1: 1) \\
\text { Ar alone }\end{array}$ & $\begin{array}{r}48.9 \\
49.5 \\
43.9 \\
86.1 \\
50.5 \\
0.0\end{array}$ & $\begin{array}{l}- \\
42.8 \\
38.0 \\
31.1 \\
24.5 \\
-\end{array}$ & $\begin{array}{l}- \\
1.16 \\
1.15 \\
2.77 \\
2.06 \\
-\end{array}$ \\
\hline $\begin{array}{l}\mathrm{Ri} \\
(1 / 6 / 75)\end{array}$ & $\begin{array}{l}\mathrm{NC} \text { alone } \\
\mathrm{NC}+\mathrm{Ri}(1: 1) \\
\mathrm{Ri} \text { alone }\end{array}$ & $\begin{array}{r}71.2 \\
0.9 \\
0.0\end{array}$ & $\begin{array}{l}- \\
35.6 \\
-\end{array}$ & $\begin{array}{c}- \\
0.03 \\
-\end{array}$ \\
\hline $\begin{array}{l}\text { Haa } \\
(1 / 27 / 75)\end{array}$ & $\begin{array}{l}\text { NC alone } \\
\text { NC + Haa }(1: 1) \\
\text { NC + Haa }(2: 1)\end{array}$ & $\begin{array}{r}10.7 \\
1.0 \\
0.0\end{array}$ & $\begin{array}{l}- \\
5.6 \\
3.6\end{array}$ & $\begin{array}{l}- \\
\ddagger \\
\ddagger\end{array}$ \\
\hline $\begin{array}{l}\text { Har } \\
(4 / 21 / 75)\end{array}$ & $\begin{array}{l}\text { NC alone } \\
\text { NC + Har }(1: 1) \\
\text { NC + Har }(1: 2) \\
\text { Har alone }\end{array}$ & $\begin{array}{r}128.9 \\
43.5 \\
10.1 \\
0.0\end{array}$ & $\begin{array}{l}- \\
64.5 \\
42.9 \\
-\end{array}$ & $\begin{array}{l}- \\
0.67 \\
0.24 \\
-\end{array}$ \\
\hline
\end{tabular}

* NC, normal control: a different individual was utilized in each mixture listed; within each group the same normal was used.

$\ddagger \mathrm{F} / \mathrm{P}$ value not calculated: normal alone generated too few $\mathrm{PC}$ for analysis.

immunodeficiency [1], Bruton-type agammaglobulinemia [1] and common variable immunodeficiency [3]) did not show the same effect of removing adherent cells.
Plasma cell generation was consistently suppressed by all fractions passed over nylon, as compared to the unseparated mononuclear layers. In these negative studies, 
the proportion of patients' NLC was reduced to $0.5-5 \%$ in the fractions tested.

\section{Effect of separation of $\mathrm{T}$ and $\mathrm{B}$ cells}

The cells of patient $\mathrm{Co}$, with common variable immunodeficiency, were co-cultured on another occasion with cells from another normal. In this experiment, borderline suppression was observed at $1: 1$ cell ratios (Table IV). Cells forming rosettes with sheep erythrocytes $(64 \%)$ were separated from nonrosetting cells on Ficoll-Hypaque gradients. Neither the unseparated cells from the patient nor the rosetting population ( $\mathrm{T}$ cells) generated plasma cells when cultured alone. The patient's cells at the interface (which included $\mathrm{T}, \mathrm{B}$, and other lymphocytes and monocytes) were capable of forming plasma cells $(65 / 1,000)$ when cultured alone.

When mixed at $1: 1$ ratios with the normal unseparated cells, the patient's $\mathrm{T}$ cells in the pellet showed a degree of suppressor activity similar to that exhibited by the unseparated monounclear cells; the patient's nonrosetting cells co-cultured with unseparated normal cells gave neither suppression nor enhancement $(F / P$ value $0.93 \pm 0.13)$. The differences in the normal control values for plasma cell generation relate to the fact that a lower cell concentration $(450,000 / \mathrm{ml})$ was used in the cultures with patient interface cells than in the cultures of unseparated $\left(1 \times 10^{8} / \mathrm{ml}\right)$ and pellet cells $(750$,$000 / \mathrm{ml}$ ), because of the low yield of interface cells. To achieve comparability of the control, the normal was cultured at the same cell concentration as were the agammaglobulinemic cells and the mixture of the two.

A second set of experiments (Table IV) with patient Co gave similar results, although, surprisingly, a few plasmacytoid cells were found in the rosetting layer as well. That layer still had suppressor activity, but to a lesser degree than had the unmanipulated cells. Similar experiments with four other patients with CVI and with the patient with thymoma did not permit plasma cell generation among cultured nonrosetting cells.

\section{Effect of agammaglobulinemic sera on cultures}

None of the 11 patient sera nor any of the normal control sera tested suppressed plasma cell generation when added to normal lymphocytes cultured with PWM under standard conditions.

TABLE III

Effect of Removing Adherent Cells

\begin{tabular}{|c|c|c|c|c|c|}
\hline \multirow{2}{*}{$\begin{array}{c}\text { Patient } \\
\text { (diagnosis) }\end{array}$} & \multirow{2}{*}{$\begin{array}{c}\text { Cells cultured } \\
\text { (\% nonlymphoid cells) }\end{array}$} & \multirow{2}{*}{$\begin{array}{c}\text { Cell ratio } \\
\text { (patient: normal) }\end{array}$} & \multicolumn{2}{|c|}{ Plasma cells $/ 1,000$ cells } & \multirow[b]{2}{*}{$\mathrm{F} / \mathbf{P}$ valu } \\
\hline & & & Found & Predicted & \\
\hline \multirow{7}{*}{$\begin{array}{l}\text { Co } \\
\text { (CVI) }\end{array}$} & $\mathrm{NC}$ & & 46.2 & - & - \\
\hline & Co $(22)+N C$ & $1: 1$ & 8.0 & 23.1 & 0.35 \\
\hline & Co (22) & & 0.0 & - & - \\
\hline & Co $(1.2)$ & & 11.4 & - & - \\
\hline & Co $(1.2)+\mathrm{NC}$ & $1: 2$ & 98.7 & 34.6 & 2.85 \\
\hline & Co $(3.4)+\mathrm{NC}$ & $1: 1$ & 94.6 & - & - \\
\hline & Co $(47.0)+\mathrm{NC}$ & $1: 1$ & 47.0 & & \\
\hline \multirow{8}{*}{$\begin{array}{l}\text { Ma (set 1) } \\
\text { (Bruton) }\end{array}$} & $\mathrm{NC}$ & & 246.2 & - & - \\
\hline & $\mathrm{Ma}(40)+\mathrm{NC}$ & $1: 1$ & 121.6 & 123.1 & 0.99 \\
\hline & $\mathrm{Ma}(40)+\mathrm{NC}$ & $2: 1$ & 21.5 & 82.1 & 0.26 \\
\hline & Ma (40) & & 0.0 & - & - \\
\hline & $\mathrm{Ma}(14)+\mathrm{NC}$ & $1: 1$ & 201.4 & $123.1^{*}$ & 1.64 \\
\hline & $\mathrm{Ma}(7)+\mathrm{NC}$ & $1: 1$ & 185.2 & $123.1^{*}$ & 1.50 \\
\hline & $\mathrm{Ma}(4)+\mathrm{NC}$ & $1: 1$ & 354.1 & $123.1^{*}$ & 2.88 \\
\hline & $\mathrm{Ma}(4)+\mathrm{NC}$ & $1: 2$ & 481.9 & 164.1 & 2.93 \\
\hline \multirow{5}{*}{$\begin{array}{l}\text { Ma (set 2) } \\
\text { (Bruton) }\end{array}$} & $\mathrm{NC}$ & & 31.2 & - & - \\
\hline & $\mathrm{Ma}(47)+\mathrm{NC}$ & $1: 1$ & 0.0 & 15.6 & 0.0 \\
\hline & $\mathrm{Ma}(23)+\mathrm{NC}$ & $1: 1$ & 6.3 & 15.6 & 0.40 \\
\hline & $\mathrm{Ma}(3)+\mathrm{NC}$ & $1: 1$ & 12.6 & 15.6 & 0.80 \\
\hline & $\mathrm{Ma}(3)+\mathrm{NC}$ & $2: 1$ & 5.2 & 10.5 & 0.50 \\
\hline \multirow{3}{*}{$\begin{array}{l}\text { Ma (set 3) } \\
\text { (Bruton) }\end{array}$} & NC & & 115.4 & - & - \\
\hline & $\mathrm{Ma}(6)+\mathrm{NC}$ & $1: 1$ & 159.8 & 112.2 & 1.42 \\
\hline & $\mathrm{Ma}(6)$ & & 0.0 & 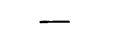 & \\
\hline
\end{tabular}

* Predicted on the assumption that removal of adherent cells would not alter the intrinsic ability of this patient's cells to differentiate, as confirmed in set 3 , this table. 


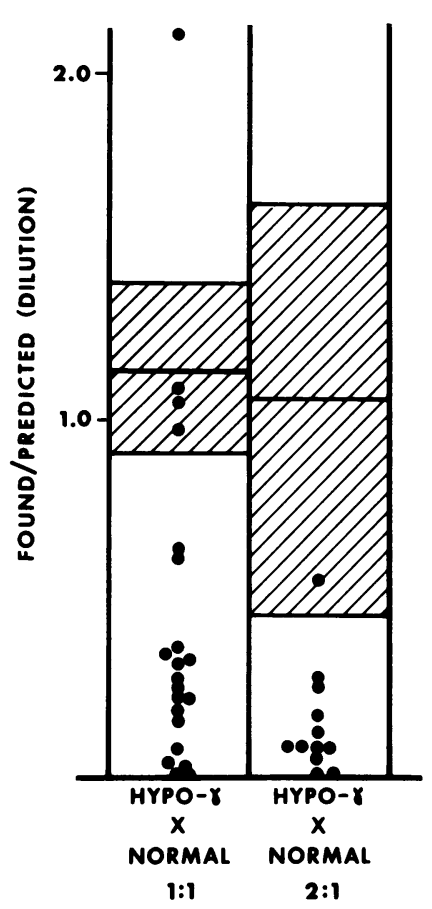

FIGURE 8 Co-cultures of cells of hypogammaglobulinemic subjects of several types (see text) and of normal subjects, at two starting cell ratios. Ordinate, $F / P$ value. Left, cell ratios of $1: 1$, patient: normal, day 0 . Right, cell ratios of 2:1, patient: normal, day 0 . Shaded area, normal mean \pm 1 SD.

\section{DISCUSSION}

The purpose of this investigation was to confirm the report of Waldmann et al. (12) that certain cells from patients with common variable immunodeficiency actively suppress terminal differentiation of B lymphocytes into plasma cells. Cell-mediated suppression of immunoglobulin secretion and of plasma cell generation could explain the pathogenesis of certain diseases of immunodeficiency, the common denominator of which is an absence of plasma cells. Such a mechanism would be particularly relevant to those patients who have a normal number of apparently normal $B$ cells in their blood and lymphoid tissue.

It was important to determine how frequently and with what significance those events occurred in patients with CVI, and whether suppressor-like activity could be detected in other primary hypogammaglobulinemias. The results of the present study confirm that in vitro suppression of terminal differentiation of $B$ lymphocytes can be produced with cells from patients with CVI. These studies also show that similar suppression occurs in patients with a variety of other hypogammaglobulinemic states of obviously differing pathogenetic mechanisms. This finding indicates that the mere demonstration of suppressor activity does not signify its importance in the pathogenesis of the disorder in which it is found.

In an experimental model, suppression seemed to be

TABLE IV

Effect of Separating $T$ and B Cells

\begin{tabular}{lllccc}
\hline \multirow{2}{*}{$\begin{array}{l}\text { Patient } \\
\text { (diagnosis) }\end{array}$} & Cells cultured & & Cell concn.* & Plasma cells/1,000 cells & \\
\cline { 5 - 6 } & & Found & Predicted & F/P value \\
\hline Co, set 1 & NC & & 93.5 & - & - \\
(CVI) & Co + NC & $1 \times 10^{6} / \mathrm{ml}$ & 29.6 & 46.8 & 0.62 \\
& Co & & 0.0 & - & - \\
& NC & & 63.8 & - & - \\
& Co B + NC & $0.45+10^{6} / \mathrm{ml}$ & 60.2 & 64.7 & 0.93 \\
& Co B & & 65.5 & - & - \\
& NC & & 86.4 & - & - \\
& Co T + NC & $0.75 \times 10^{6} / \mathrm{ml}$ & 29.9 & 43.2 & 0.69 \\
& Co T & & 0.0 & - & - \\
Co, set 2 & NC & & 61.0 & - & - \\
(CVI) & Co + NC & $1 \times 10^{6} / \mathrm{ml}$ & 0.0 & 30.5 & 0 \\
& Co & & 0.0 & - & - \\
& Co B & $0.5 \times 10^{6} / \mathrm{ml}$ & 59.5 & & \\
& Co T & $1 \times 10^{6} / \mathrm{ml}$ & 5.9 & - & - \\
& Co T + NC & $1 \times 10^{6} / \mathrm{ml}$ & 6.0 & 33.5 & 0.18 \\
\hline
\end{tabular}

* Cell concentrations within a triplet were determined by the number of patient cells available after separation. See text. 
secondary to antibody (or B-cell) deficiency. Blaese et al. recently reported $(20,21)$ experiments in which chickens rendered agammaglobulinemic by bursectomy and irradiation ultimately develop cells which, on transfer to otherwise normal birds of the same inbred strain, reduce circulating gamma globulin levels in the recipients. In this model, removal of the source of $B$ cells (the bursa of Fabricius) and irradiation (to kill perpiheralized $B$ cells) not only leads to agammaglobulinemia, but also, eventually, to the development of cells which suppress immunoglobulin synthesis in other birds. Here the suppressor population develops as a consequence of B-cell deficiency.

The experimental system in the present studies takes advantage of the ability of PWM to drive fully-formed B lymphocytes to differentiate into plasma cells $(7,8$, $11,12)$. When cultured with this agent, cells of most of our hypogammaglobulinemic subjects were distinguished from normal cells by their almost complete inability to undergo those final differentiative steps. Wu et al. (7), Waldmann et al. (12), and Geha et al. (13) have made similar observations, although a later publication of $\mathrm{Wu}$ et al. (8) suggests this may not be universally true of such patients. One of our patients (Ro), whose father (not studied) had selective IgA deficiency, did make normal numbers of plasmacytoid cells on two of three occasions, and always produced some stainable cells. Interestingly, even this patient showed some suppressor activity on two occasions.

Cells from patients with Bruton-type agammaglobulinemia (presumably $\mathrm{X}$-linked agammaglobulinemia) and thymoma with immunodeficiency produced suppressive effects similar to those observed with cells from patients with CVI.

The prototype of the suppression originally described by Waldmann is seen in patients with CVI. Most such patients have $B$ cells that have developed to cells with surface markers identical to those of normal individuals. Such cells have apparently normal amounts of intrinsic surface $\operatorname{Ig}$ (IgM, IgD) as detected by immunofluorescence, indicating the ability of these patients to synthesize the immunoglobulin molecules and insert them into the cell membranes $(5,9,13,15,22)$. The B cells of many of these patients had, before Waldmann's observation, usually been considered to be functionally incapable of undergoing further differentiation into secreting cells (7). Biochemical studies led to similar conclusions (10). All eight patients in this series having a diagnosis of CVI had B cells in normal numbers (defined by the presence of IgM- and IgD-bearing lymphocytes). All exhibited at least some capacity to suppress PWMdriven terminal differentiation when co-cultured with cells from normal persons. Manipulations designed to remove suppressing cells either by rosetting or by ad- herence to nylon wool columns did permit terminal differentiation in the cells of one patient tested. The several failures may have been attributable to technical difficulties as yet undefined, such as incomplete removal of suppressors. However, the unsuccessful experiments were notable for their more efficient separation of $B$ and $\mathrm{T}$ cells and by their better recoveries. Another possibility is that more efficient separations removed helper cells involved in plasma cell production. The results may indicate that suppressor cells, found even in CVI, are not always pathogenic. Our findings suggest that $\mathrm{B}$ cells of some but not other patients with CVI can differentiate to plasma cells in the absence of suppressors. Those patients who cells cannot so differentiate would need be considered to have either intrinsic cellular defects or other factors of the internal milieu which prevent terminal differentiation. The application of these new criteria reveals, in still another way, that CVI is a variable group of diseases very likely based on different mechanisms.

The finding of excess suppressor cell activity in the patients with Bruton's agammaglobulinemia initially was surprising. Unlike CVI, this disease is characterized usually by a lack of $B$ lymphocytes in peripheral blood and lack of germinal centers in stimulated lymphoid tissue. While a few patients having this diagnosis seem to have cells carrying $\operatorname{IgM}$ or other immunoglobulin classes, most do not $(3,5,6,9,22)$. A proportion of the cells which circulate in these patients carry other markers found on $\mathrm{B}$ cells (Fc receptors, complement receptors, lack of sheep-rosetting capacity); it remains uncertain whether the latter are B cells incapable of developing surface and intracytoplasmic Ig, though equipped with the structural gene (5) for Ig synthesis, or whether they represent a third population of lymphoid cells $(6,22)$. In spite of these indications that B cells are lacking in Bruton-type agammaglobulinemia, it is possible that the primary pathogenesis of this disease relates to an X-linked genetically determined presence of suppressor cells. Such suppressors could act early in the differentiation of the $\mathrm{B}$ cells, preventing development or interfering with the capacity to generate cell surface (intrinsic) immunoglobulin, presumably $\operatorname{IgM}$ or $\operatorname{IgD}$ (5). The suppressing cells found in this study seem to have the capacity to inhibit late steps of differentiation from fully-formed B cells to plasma cells, since the cocultures with normal ( $B$ and $T$ ) cells showed suppression of terminal differentiation. Cells of pathogenic significance in the Bruton agammaglobulinemic would have to have activity on at least two steps in the course of differentiation of the B cells. Such suppression would stop B-cell development both at the precursor stage (in the patients) and at the terminal stages of differentiation, as in the mixed culture analysis used. 
An alternative, and perhaps better, hypothesis is that the suppressor activity observed in the patients with Bruton's agammaglobulinemia is similar to that seen in the chicken model of Blaese et al. discussed above (20). In this interpretation, a genetically determined defect of B-cell differentiation would lead to generation of a suppressor population of cells. That this is the case is suggested by the failure of the cells of such patients to generate plasma cells in culture after removal on nylon columns of cells suppressing terminal differentiation. In one case, plasma cells were not found despite the fact that the remaining nonadherent cells actually seemed to enhance plasma cell generation by normal cells in mixed culture.

The pathogenesis of the thymoma-agammaglobulinemia syndrome is not well understood. In the patient studied here as well as in other patients (6), cells which carry intrinsic surface Ig have been absent, although precursors of such cells may circulate (6). The finding of suppressors in such patients, as also recently reported by Waldmann et al. (23), lends additional weight to the doubts about the primary role of the suppressors, by arguments similar to those expressed above.

Cells involved in suppression may be heterogeneous. In certain patients, removal of nylon-adherent cells removed the suppressive effects on normal lymphocytes, and indeed revealed enhancement of plasma cell formation in those mixed cultures. The cells of one patient with Bruton's agammaglobulinemia and one with CVI exhibited such enhancing influences. Passage of the latter's cells through a nylon column permitted generation of a few plasma cells among the cells cultured from column effluents. These data indicate that an adherent cell participates in the suppressor effects. Since moncytes are a major class of adherent cells, attempts were made to restore suppression by adding back the monocytes. In one experiment, a column eluate containing $46 \%$ monocytes failed to suppress plasma cell morphogenesis, although the unseparated cells had been suppressive. Moreover, effective removal of monocytes by nylon columns from the suppressive cells of other patients to as few as $0.5 \%$ did not remove suppressor activity. These results suggest that it is not the monocytes themselves which are suppressing plasma cell formation in these patients. The recovery of lymphocytes from the nylon columns was only $60-70 \%$. Lymphoid as well as monocytoid cells were removed by adherence to the column. There may have been selective loss of a functionally suppressive subpopulation of lymphocytes. If the suppressors lost on the nylon columns were, indeed, lymphocytes, the proportion of monocytes might merely be a measure of the effectiveness of the adherence column in removing adherent cells. Because adherence columns have been found by Folch and Waksman to remove cells apparently suppressing lymphocyte mitogenic responses as measured by incorporation of tritiated thymidine, these workers postulated that a monocyte/T-cell complex might be involved in certain forms of suppression (24).

Cells spontaneously forming rosettes with sheep erythrocytes (presumably $\mathrm{T}$ cells) seem to be implicated as suppressors in at least one of our patients (Co), as in one of the cases reported by Waldmann et al. (12). When Co's rosetting cells were separated from nonrosette-forming cells, the rosetting cells continued to show some suppressor activity, although a net loss of suppressors during the separation appears to have occurred. The nonrosetting cells, as well as some cells carried down into the rosetting fraction, seemed released to generate plasma cells when cultured alone. The patient in which these differential effects were seen was the same patient in whom removal of adherent cells permitted terminal differentiation to plasma cells. This finding would suggest that either adherent $T$ cells or a complex of $T$ cells and adherent cells was necessary for suppression in that patient. Of possible significance is the finding that, in Co, removal of adherent cells seemed to have two effects: (a) the elimination of suppression, and $(b)$ a revealing of an enhancing effect of the remaining cells in co-culture. By contrast, removal of $\mathrm{T}$ cells by rosetting seemed only to remove suppressing activity. The remaining cells did not enhance plasma cell generation in the mixed cultures. This could mean that the $T$ cells removed by rosetting included both helper and suppressor cells, while the cells removed by nylon included cells participating in suppression, but did not include helper cells.

The mechanism of the suppressing event observed needs to be further defined. Humoral mediators have been reported to be suppressive. Sera of our patients were not suppressive. This does not rule out the possibility that a humoral mechanism (rather than cell to cell contact) is involved. The lack of serum inhibition reduces the possibility that small amounts of serum factors carried over with the washed mononuclear cells were actually responsible for suppression in the system studied. Supernates of the suppressing cultures are being investigated to assess their effects in vitro.

In most of these experiments, the viability of cells was essentially the same when normal cells or cells of immunodeficient patients were cultured alone or together in the several possible combinations. Co-cultures in which plasma cell generation was severely suppressed possessed as many viable cells as did co-cultures in which no suppression was observed. The results cannot be explained by a generalized "toxic" effect on the cultures, although a selective (antiproliferative?) effect on B cells (pres- 
ent at about $5 \%$ in the starting cultures) could account for the results.

Allogeneic interactions in vitro do not appear to play a significant role in the suppressor phenomena observed for several reasons. First, autologous suppression seems a reality, since it could be removed and reveal, as in Co, the ability of the patient's own cells to differentiate. Second, some suppression was observed between hypogammaglobulinemic and normal members of an identical twin pair $(\mathrm{Ka})$. Third, mixed-lymphocyte culture-reactive normals failed to suppress one another; while there may be some individual exceptions to this, overall, the allogeneic effects between normals appeared to enhance plasmacytoid cell production in this system $(\mathrm{F} / \mathrm{P}$ ratios greater than 1.0).

An interesting speculation concerns the role of PWM in generating the suppressor cell activity. In these studies, we added PWM to evaluate the development of plasma cells. It is possible that PWM activated suppressors present in these patients' cells. Similar effects are induced by concanavalin $\mathrm{A}$ in a murine plaque-forming cell assay (25). Such in vitro events could conceivably mimic the constant exposure to antigens of a wide range of specificities which could activate abnormally susceptible or populous cells in certain people, which would then produce a general tolerance-like state and lead, ultimately, to agammaglobulinemia. In others, the imbalance created by immunodeficiency might select for cells more likely to respond to this kind of activation.

Another question that must be raised is whether the suppressor cells observed in these patients are selectively affecting $B$ cells, or whether they suppress $T$-cell functions and (or) other cell populations as well. The clinical data seem to indicate that in most of these cases, suppression is selective for B-cell differentiation. T-cell proliferation in response to PWM and other mitogens was apparently unaffected in most patients. Furthermore, many of the patients who showed severe degrees of plasma cell suppression have apparently normal cellmediated immunity both in vivo and in vitro.

The potential for clinical application of the information gained from investigation of suppressor cells in man is great. Definition of the role of suppressors in individual patients with immunodeficiency seems necessary if appropriate therapy is to be identified. For the treatment of patients with significant suppressor activity, methods need to be developed which will selectively remove it or render it nonfunctional. Perhaps adherence to nylon wool in a cell separator, or pharmacologic or serologic techniques can be used. In other patients, such efforts might be unsuccessful, when the defect is intrinsic to the B cell, and the suppressor population represents a secondary development. Rational therapy and a basic understanding of these disorders depends upon patient-by-patient dissection of the defects pathogenetic in the immunodeficiency disease.

Addendum. Since original submission of this paper, a report has appeared confirming the existence of suppressor cells in some patients with CVI (cultured at $1: 1$ ratios), and finding, as we did, reduced or absent plasma cell generation in most patients with this form of immunodeficiency (26).

\section{ACKNOWLEDGMENTS}

The authors gratefully acknowledge the participation in these studies of the patients and staff of the Clinical Immunology A Clinic of the Memorial Hospital for Cancer and Allied Diseases, with particular thanks to Doctors $\mathrm{R}$. J. O'Reilly, E. M. Smithwick, S. Schwartz, S. Gupta, S. Tannenbaum, S. Pahwa, R. Pahwa, and E. Grimes, and Ms. J. Nimkin. Dr. J. Pitt kindly allowed us to study cells from her patient. Doctors M. Siniscalco and E. Seravalli gave valuable advice on the cell cultures, and Doctors Edward Binkowski and Howard Thaler of the Biostatistics Laboratory provided the statistical analysis. The excellent technical assistance of Ms. K. Shah is very much appreciated.

These studies were supported in part by U. S. Public Health Service Research grants CA-05826, CA-08748, and CA-17404 from the National Cancer Institute; grant no. AI11843 from the National Institute of Allergy and Infectious Diseases; and grants from the American Cancer Society, and the National Foundation.

\section{REFERENCES}

1. Good, R. A. 1955. Studies on agammaglobulinemia. II. Failure of plasma cell formation in the bone marrow and lymph nodes of patients with agammaglobulinemia. J. Lab. Clin. Med. 46: 167-181.

2. Crabbé, P. A., and J. F. Heremans. 1966. The distribution of immunoglobulin-containing cells along the human gastrointestinal tract. Gastrocnterology. 51: 305-316.

3. Cooper, M. D., W. P. Faulk, H. H. Fudenberg, R. A. Good, W. Hitzig, H. Kunkel, F. S. Rosen, M. Seligmann, J. Soothill, and R. J. Wedgwood. 1973. Classification of primary immunodeficiencies. N. Engl. J. Med. 288: 966-967.

4. Möller, G., editor. 1973. T and B lymphocytes in humans. Transplant. Rev. 16: 3-217.

5. Cooper, M. D., R. G. Keightley, L. Y. F. Wu, and A. R. Lawton, III. 1973. Developmental defects of $T$ and $B$ cell lines in humans. Transplant. Rev. 16: 51-84.

6. Siegal, F. P., P. Wernet, H. B. Dickler, S. M. Fu, and H. G. Kunkel. 1975. B lymphocytes lacking surface Ig in patients with immune deficiency: Initiation of $\mathrm{Ig}$ synthesis in culture in cells of a patient with thymoma. In Immunodeficiency in Man and Animals. Birth Defects Original Article Series XI. D. Bergsma, editor. Sinauer Assoc., Sunderland, Mass. 40-44.

7. Wu, L. Y. F., A. R. Lawton, M. F. Greaves, and M. D. Cooper. 1973. Evaluation of human B lymphocyte differentiation using pokeweed mitogen (PWM) stimulation: In vitro studies in various antibody deficiency syndromes. Proc. Leucocyte Cult. Conf. 7: 485-500.

8. Wu, L. Y. F., A. R. Lawton, and M. D. Cooper. 1973. Differentiation capacity of cultured B lymphocytes from immunodeficient patients. J. Clin. Invest. 52: 3180-3189.

9. Siegal, F. P., B. Pernis, and H. G. Kunkel. 1971. Lymphocytes in human immunodeficiency states: A study of 
membrane-associated immunoglobulins. Eur. J. Immunol. 1: 482-486.

10. Choi, Y. S., W. D. Biggar, and R. A. Good. 1972. Biosynthesis and secretion of immunoglobulins by peripheral-blood lymphocytes in severe hypogammaglobulinemia. Lancet. I : 1149-1152.

11. Douglas, S. D. 1971. Human lymphocyte growth in vitro: Morphologic, biochemical and immunologic significance. Int. Rev. Exp. Pathol. 10: 41-114.

12. Waldmann, T. A., M. Durm, S. Broder, M. Blackman, R. M. Blaese, and W. Strober. 1974. Role of suppressor $\mathrm{T}$ cells in pathogenesis of common variable hypogammaglobulinaemia. Lancet. II : 609-613.

13. Geha, R. S., E. Schneeberger, E. Merler, and F. S. Rosen. 1974. Heterogeneity of "acquired" or common variable agammaglobulinemia. N. Engl. J. Med. 291: $1-6$.

14. Gershon, R. K. 1974. T cell control of antibody production. Contemp. Top. Immunobiol. 3: 1-40.

15. Fudenberg, H. H., R. A. Good, H. C. Goodman, W. Hitzig, H. G. Kunkel, I. M. Roitt, F. S. Rosen, D. S. Rowe, M. Seligmann, and J. R. Soothill. 1971. Primary immunodeficiencies. Report of a world health organization committee. Pediatrics. 47 : 927-946.

16. Böyum, A. 1968. Isolation of mononuclear cells and granulocytes from human blood. Isolation of mononuclear cells by one centrifugation, and of granulocytes by combining centrifugation and sedimentation at $1 \mathrm{~g}$. Scand. J. Clin. Lab. Invest. Suppl. 97: (21) 77-89.

17. Bentwich, Z., S. D. Douglas, F. P. Siegal, and H. G. Kunkel. 1973. Human lymphocyte-sheep erythrocyte rosette formation: Some characteristics of the interaction. Clin. Immunol. Immunopathol. 1: 511-522.

18. Hansen, J., C. D. Bloomfield, B. Dupont, K-J. Gaij1Peczalska, D. Kiszkiss, and R. A. Good. 1973. Lymphocyte subpopulations and immunodeficiency in lymphoproliferative malignancies. Proc. Leucocyte Cult. Conf. 8: $119-125$.
19. Aiuti, F., J-C. Cerottini, R. R. A. Coombs, M. Cooper, H. B. Dickler, S. S. Fr $\phi$ land, H. H. Fudenberg, M. F. Greaves, H. M. Grey, H. G. Kunkel, J. B. Natvig, J-L. Preud'homme, E. Rabellino, R. E. Ritts, D. S. Rowe, M. Seligmann, F. P. Siegal, J. Stjernswärd, W. D. Terry, and J. Wybran. 1974. Identification, enumeration and isolation of $\mathrm{B}$ and $\mathrm{T}$ lymphocytes from human peripheral blood. Report of a WHO/IARC-sponsored workshop of human B and T cells, London, 15-17 July 1974. Scand J. Immunol. 3: 521-532.

20. Blaese, R. M., P. L. Weiden, I. Koski, and N. Dooley. 1974. Infectious agammaglobulinemia: Transmission of immunodeficiency with grafts of agammaglobulinemic cells. J. Exp. Med. 140: 1097-1101.

21. Blaese, R. M., J. W. Peng, A. Muchmore, N. Dooley, and I. Koski. 1975. T suppressor cells as mediators of infectious agammaglobulinemia. Fed. Proc. 34: 1031. (Abstr.)

22. Frøland, S. S., and J. B. Natvig. 1973. Identification of three different human lymphocyte populations by surface markers. Transplant. Rev. 16: 114-162.

23. Waldmann, T. A., S. Broder, M. Durm, M. Blackman, R. Krakauer, and B. Meade. 1975. The role of suppressor $\mathrm{T}$ cells in the pathogenesis of hypogammaglobulinemia with a thymoma. Trans. Assoc. Am. Physicians Phila. In press.

24. Folch, H., and B. H. Waksman. 1973. Regulation of lymphocyte responses in vitro. V. Suppressor activity of adherent and nonadherent rat lymphoid cells. Cell. Immunol. $9:$ 12-24.

25. Tadakuma, T., A. Kühner, J. David, and C. Pierce. 1975. Characterization of a soluble immune response suppressor (SIRS) produced by lymphocytes. Fed. Proc. 34 : 838. (Abstr.)

26. Broom, B. C., I. G. De La Concha, A. D. B. Webster, G. J. Janossy, and G. L. Asherton. 1976. Intracellular immunoglobulin production in vitro by lymphocytes from patients with hypogammaglobulinaemia and their effect on normal lymphocytes. Clin. Exp. Immunol. 23 : 73-77. 